\title{
Tool of Automated System Armoured Scaffold to Rank Requirements through AHP
}

\author{
K Glory Vijayaselvi, ThirumalaiSelvi R
}

\begin{abstract}
Requirement Engineering is really significant phase in software development life cycle. Construction of software and its functionalities is entirelygrounded on the requirements elicited for the project[6]. In this paper, we propose a tool to prioritize the requirements only with AHP bearing in mind effortless implementation for large Scale Application, Precision of result and Stakeholder's Contribution. The tool is developed in Java and SQL. This work principallyfocused on applying AHP for larger projects. The proposed framework has been assessed through an exploratory case study that has fixed number of requirements and the status after the arrival of new requirements to the priority list. This is to know about the certainty of the projected framework, which has been conducted in a software firm. Then the tool was developed for the framework and used by the company to check for the certainty of result. The deployment of the tool and the result obtained from the effort are presented.
\end{abstract}

Key Words: AHP, Tool, Requirement prioritization, Users, comparisons, priority.

\section{INTRODUCTION}

Creation of software in addition to its functionalities is completelygrounded on the requirement. Since all the provoked requirements cannot be established and delivered in a sole delivery, prioritizing the requirement that has to be developed for each and every release is vital.

According to Firesmith [7] , requirement prioritization is the process of determining the implementation direction of the requirement for a software system.

From the review, it is found out that requirement prioritization condenses the development cost of the software system and time taken by forty percentage. The requirement prioritization also upsurges the gratification among the customers and also increases the excellence of a software. Hence this requirement prioritization is very important process in SDLC. Automizing the process helps the developing team to easily find out the priority among the requirements and in decision making. Hence the tool was developed with the intention to reduce the effort spend to find the priority among the requirement in quantitatively.

Revised Manuscript Received on December 30, 2019.

* Correspondence Author

K Glory Vijayaselvi*, Research Scholar, Research and Development Centre, Bharathiar University, Coimbatore \& Assistant Professor, Department of Computer Science (Shift II), Women's Christian College, Chennai, India. E-mail: gloryvijayaselvi@yahoo.com,

Thirumalai Selvi R, Assistant Professor, Department of Computer Science, Govt. Arts College for Men, Nandanam, Chennai, India. E-mail: saraselvi@gmail.com

(C) The Authors. Published by Blue Eyes Intelligence Engineering and Sciences Publication (BEIESP). This is an open access article under the CC BY-NC-ND license (http://creativecommons.org/licenses/by-nc-nd/4.0/)

\section{FACTORS THAT CAN BE CONSIDERED FOR REQUIREMENT PRIORITIZATION}

While prioritizing the requirement, normsare there to consider. It differs based on the nature of the project. Some common criterion are

\section{- $\quad$ Status/ insistence of the requirement}

- $\quad$ Time occupied for the enactment of requirement

- $\quad$ Outlay for the implementation of requirement

- Challenges to be met if the requirement is not implemented

- $\quad$ Others eg. perils, exterior factors, etc.,

\section{RELATED WORK}

Proper selection of the requirement having high significance is important to gain customer satisfaction and fruitfulperformance of the company ${ }^{[1]}$

AHP is used to scrutinize relative importance of each requirement but the time taken to perform the calculation is high and the method is not scalable ${ }^{[3]}$. When thenumber of requirement is too bulky, then it is intricate to adopt this method.

If the number of requirements is small, then AHP can be preferred $^{[5]}$. Since, it is accurate, this type of result is chosen. But because of its convolution in large scale projects, it is very difficult to implement.

When numerous stakeholders and requirements involved, then it is actually difficult to construct the priority list of requirements using $\mathrm{AHP}^{[6]}$. The authors specified that AHP chomps more time and not extendable.Hence there is a need for the technique that will have the capability to put up large number of stakeholders and requirements.

Shahid Nazir Bhatti ${ }^{[2]}$,evaluated related papers to analyse the requirement prioritization approaches. AHP yields healthier result than others and very useful in decision making. Future work is proposed as complete automation of software engineering process. And also decided that the existing prioritization systems are not appropriate for all types of projects.

Tschangho John $\mathrm{Kin}^{[4]}$, improved or substitute approach for AHP was proposed. Excel spread sheet is used to calculate, which is recommended as an relaxed method. 


\section{HUMAN INVOLVEMENT AND THE REQUIREMENT PRIORITIZATION}

The prioritization procedure makes the user to involve in the developmental process. Since the user's involvement throughout the development of the software is considered as very important, the HCC Model [8] is proposed with the user involvement and human inducement as a research work.

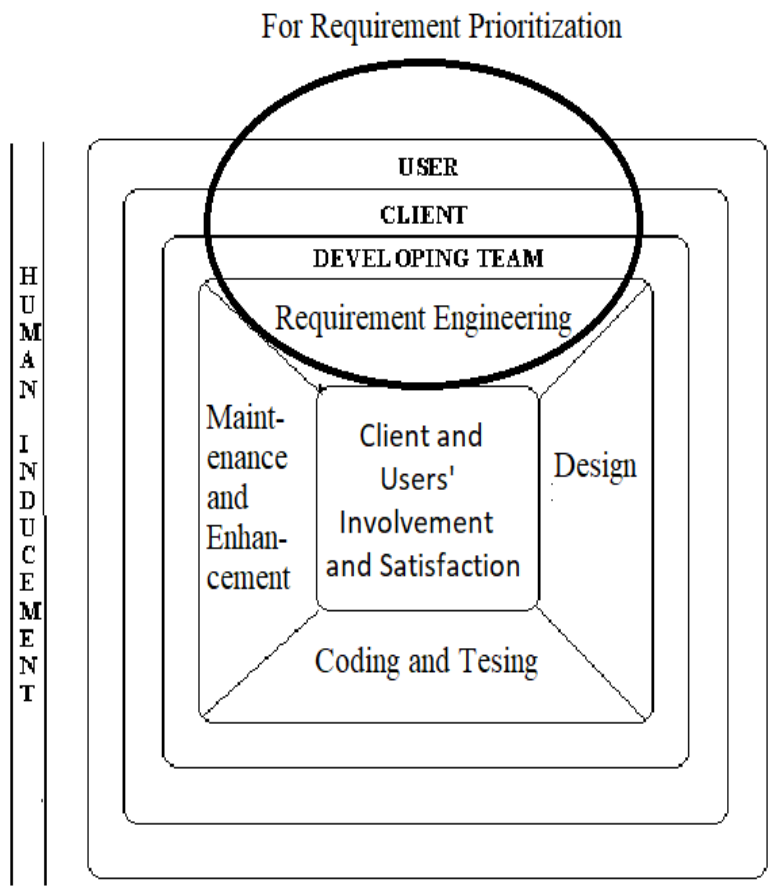

Figure 1 . New Proposed HCC Model

Including stakeholders in all the chapters helps the fruitful implementation of required requirement at required period. It lessens the software letdown. This also supports to manage the resources with bestconsumption which is very important in this current competitive world.

But collecting and consolidating the requirement prioritization from diverse stakeholder is problematic. Within the specified time, the priority list has to be prepared. Hence human inducement is very much important in this process to make the stakeholders to participate in the work interestingly.

\section{AHP METHOD}

In AHP, one compares all the probable pairs of requirements to find out well-organized list of the requirements according to their consequence. Usually the values $1,3,5,7$ and 9 is used, where 1 denotes alike importance and 9 represents tremendously high importance. During the headway, if inumber of requirements are elicited, $i \times(i-1) / 2$ comparisons want to be completed, which for the application with huge number of requirements results in scuffle. The result is a set of requirements prioritized along a measure. The AHP combines multidimensional scales of measurement into a one-dimensional scale of significances. AHP is highly trustworthy, since the great level of redundancy in the pair wise comparisons makes the process resistant to comparison errors. Another advantage is the fact that the standards assigned in the pair wise comparisons are based on familiarity, observation and real data. Thus, AHP can handle both the qualitative and the quantitative facets of a decision problem. As a result, the fact that the resulting priorities are related and based on a scale certificates useful valuations of the requirements. The elicited value $\mathrm{m}_{i j}$ is inserted in the corresponding cell of the matrix $\left(\mathrm{m}_{i}, m_{j}\right)$, while the cell $\left(\mathrm{m}_{j}, j_{i}\right)$ is filled with the reciprocal of the value $\mathrm{m}_{j i}=1 / \mathrm{m}_{i j}$

Hence AHP method is satisfactory with multi criteria decision making. The steps of AHP are as follows:

1. Entryof the criteria

2. Pair wise assessment of criteria for earnestness

3. Building of normalized comparison matrix

4. Amalgamationof matrix

5. Calculation of AHP score (priority) for each criteria

The values used for criterion comparison are

\begin{tabular}{|c|l|}
\hline Value & Description \\
\hline I & Equal weight \\
\hline III & $\begin{array}{l}\text { First (row) criteria is important } \\
\text { than second (column) one. }\end{array}$ \\
\hline V & $\begin{array}{l}\text { First (row) criteria is much more } \\
\text { important than second (column) one. }\end{array}$ \\
\hline VII & $\begin{array}{l}\text { First (row) criteria is significantly } \\
\text { more important than second (column) } \\
\text { one. }\end{array}$ \\
\hline IX & $\begin{array}{l}\text { First (row) criteria is definitely } \\
\text { more important than second(column) } \\
\text { one. }\end{array}$ \\
\hline
\end{tabular}

Table1- Priority Scale

\section{THE PROPOSED FRAMEWORK}

This paper proposes innovative framework which gears only AHP in all its phases. Because of the precision of the method, the AHP entices more in prioritization. Accuracy is an essential constraint. Others stand in the following. So with this AHP, the framework is planned to prepare the prioritized list. In this work, the parameters considered are number of requirements, number of users, number of comparisons and the priority of the requirement. 


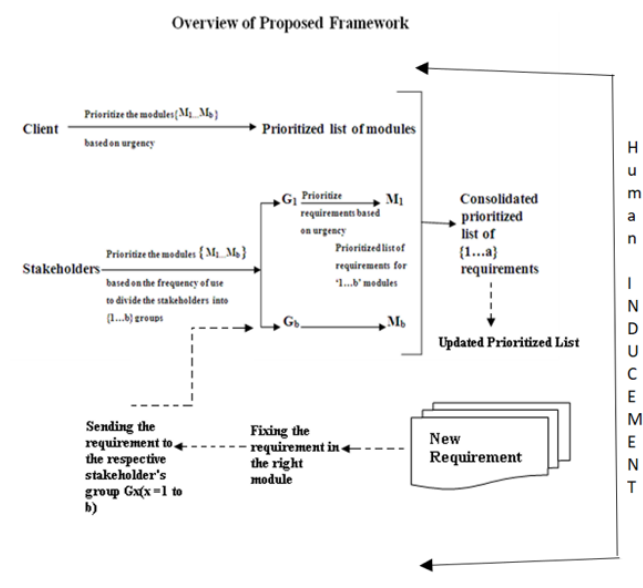

Credits to all the participated stakeholders

Figure 2- Framework

This framework is to identify the stakeholder's preference on what the system should have from their former implementation to concluding implementation. This ranking will direct the developers to try their finest to satisfy stakeholders by their software. The framework practices only AHP method to find the priority of requirement. It will work for any number of requirements and any number of participants. The quantitative assessments given to the requirement leads to erroneous priority list. Also, those who tangled in this process may not work with curiosity if they will not get any benefit. Considering these limitations, the PAS framework has the parameter 'human inducement' to encourage and involve the stakeholders to participate in the process with enthusiasm. It is designed to give points to the stakeholders for their response given in the AHP sheet. Later, these credits can be used to give profits to the stakeholders involved in the progression.

\section{DIFFICULTIES FACED TO COLLECT THE DATA BASED ON THE FRAMEWORK PROPOSED}

A. Google Forms wereused for creating surveys for one of my research projects. Easy to use interface makes creating and deploying forms easy.Users can enter their "answer" and it will be submitted into a spreadsheet. The stakeholders' mail id will be collected. They will be provided with the sheet. The forms are integrated with Google Sheets which gives a spreadsheet view of the data collected, making it easy to analyze. Calculations has to be made using the quantitative data collected. It will be easy, if separate account is maintained to all the stakeholders to have their details and credits earned.

Sample google form used

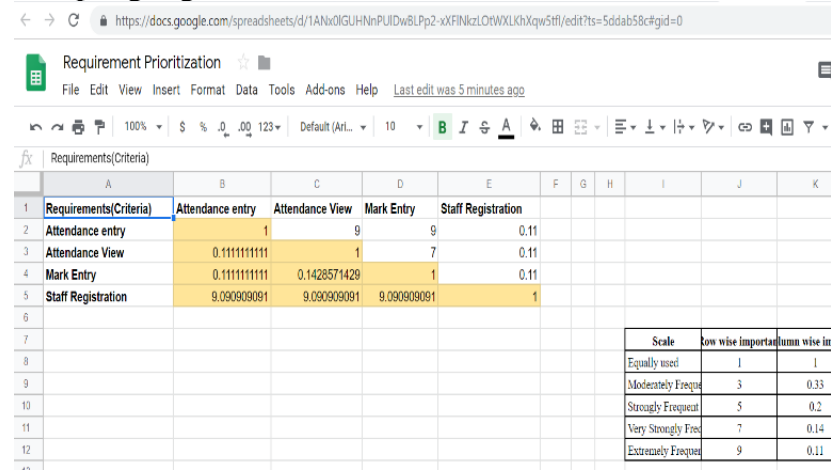

Figure 3 - Google form

B. Through Sheet (Hard copy). A sheet with AHP table is used. It is circulated among the stakeholders to collect the data. This resulted in time consuming and more effort. Then the data has to be feed in the system for further calculation and decision making. The stakeholder no need to fill the shaded cell. After collecting the data in the sheet, formula in Excel is used to perform calculation.

\begin{tabular}{|c|c|c|c|c|c|c|c|c|c|c|c|c|}
\hline Requirements & $\mathrm{R} 1$ & $\mathrm{R} 2$ & $\mathrm{R} 3$ & $\mathrm{R} 4$ & $\mathrm{R} 5$ & $\mathrm{R} 6$ & $\mathrm{R} 7$ & $\mathrm{R} 8$ & $\mathrm{R} 9$ & $\mathrm{R} 10$ & $\mathrm{R} 11$ & $\mathrm{R} 12$ \\
\hline $\mathrm{R} 1$ & 1 & 9 & 9 & 9 & 9 & 9 & 9 & 9 & 9 & 9 & 9 & 9 \\
\hline R2 & 0.11 & 1.00 & 9.00 & 9.00 & 7.00 & 9.00 & 9.00 & 9.00 & 9.00 & 9.00 & 9.00 & 9.00 \\
\hline R3 & 0.11 & 0.11 & 1.00 & 9.00 & 3.00 & 3.00 & 7.00 & 5.00 & 7.00 & 5.00 & 7.00 & 9.00 \\
\hline R4 & 0.11 & 0.11 & 0.11 & 1.00 & 5.00 & 3.00 & 7.00 & 9.00 & 3.00 & 0.20 & 9.00 & 9.00 \\
\hline R5 & 0.11 & 0.14 & 0.33 & 0.20 & 1.00 & 9.00 & 7.00 & 7.00 & 7.00 & 0.11 & 9.00 & 9.00 \\
\hline R6 & 0.11 & 0.11 & 0.33 & 0.33 & 0.11 & 1.00 & 7.00 & 3.00 & 7.00 & 0.11 & 9.00 & 9.00 \\
\hline R7 & 0.11 & 0.11 & 0.14 & 0.14 & 0.14 & 0.14 & 1.00 & 0.33 & 5.00 & 0.33 & 7.00 & 9.00 \\
\hline R8 & 0.11 & 0.11 & 0.20 & 0.11 & 0.14 & 0.33 & 3.03 & 1.00 & 7.00 & 0.11 & 9.00 & 9.00 \\
\hline R9 & 0.11 & 0.11 & 0.14 & 0.33 & 0.14 & 0.14 & 0.20 & 0.14 & 1.00 & 0.11 & 9.00 & 9.00 \\
\hline R10 & 0.11 & 0.11 & 0.20 & 5.00 & 9.09 & 9.09 & 3.03 & 9.09 & 9.09 & 1.00 & 9.00 & 9.00 \\
\hline R11 & 0.11 & 0.11 & 0.14 & 0.11 & 0.11 & 0.11 & 0.14 & 0.11 & 0.11 & 0.11 & 1.00 & 7.00 \\
\hline R12 & 0.11 & 0.11 & 0.11 & 0.11 & 0.11 & 0.11 & 0.11 & 0.11 & 0.11 & 0.11 & 0.14 & 1.00 \\
\hline Total & 2.22 & 11.14 & 20.72 & 34.34 & 34.85 & 43.93 & 53.51 & 52.79 & 64.31 & 25.19 & 87.14 & 98 \\
\hline
\end{tabular}

Table 2 - Priority given for all requirements by a single user 
C. Using Excel.Thenormalization of AHP is made in excel using formulae.All the other following calculations to select the precise end user to prioritize the requirements and the priority list generation are made manually in the Excel, which is also a tedious job.

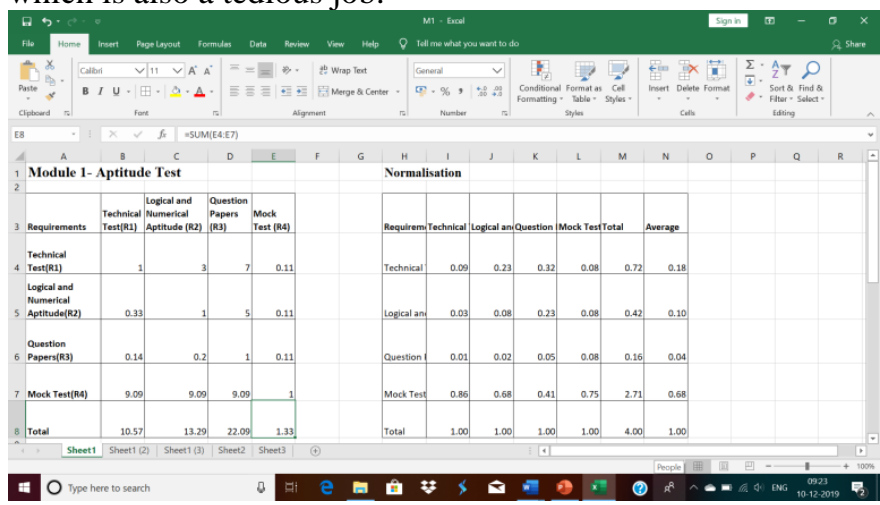

Figure 4 - Excel sheet (AHP)

\section{VIII.THE TOOL}

The tool is developed with Java and SQL. The developed web tool will be very helpful for the developers in finding the priority among the requirements. The architectural view of the proposed tool

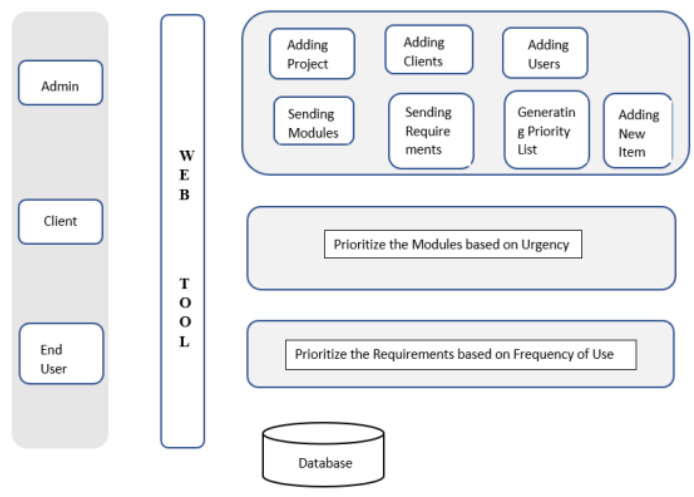

Figure 5 - Architecture of the tool

\section{A. Advantages of Using tool}

1. Capability to help decision makers to select the suitable requirement for development

2. Flexible and quantitative decision analysis tool. Quantitative verdict

3. Capability to select best substitute under dynamically changing circumstances

4. Numerous inputs can be considered

5. Ability to handle interrelationship among criteria

6. Capacity to deal with large scale problems

7. Better communication with stakeholders

8. Remote working

9. $\quad$ Easy document sharing

10. No need of space in the hardware.

\section{B. GUI of tool}

First, the company has to register and login. Then the development team has to select the project from menu(new/existing), add the details about the project , clients and the end users.

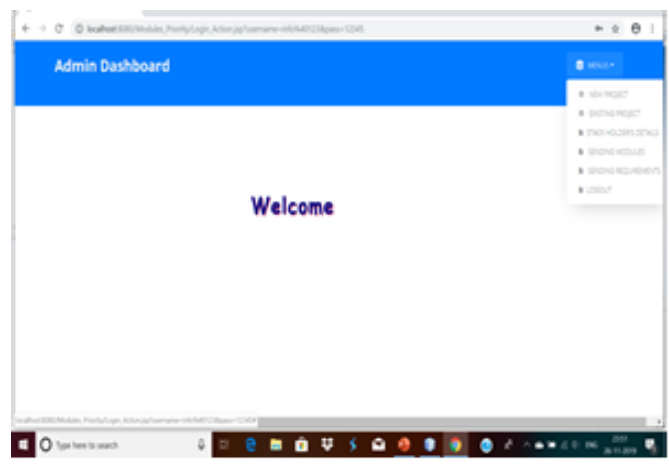

Figure 6- Home page

\section{Infotech}

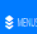

Add New Project

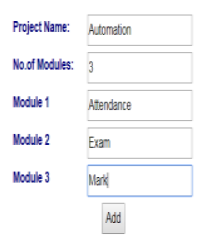

Figure 7 - Interface to add the project

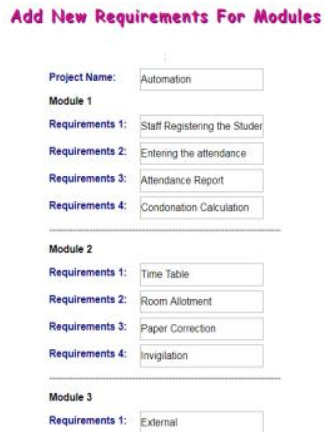

Figure 8 - Requirement specification page

After submitting the details, first the modules will be sent to the clients and end users for prioritization

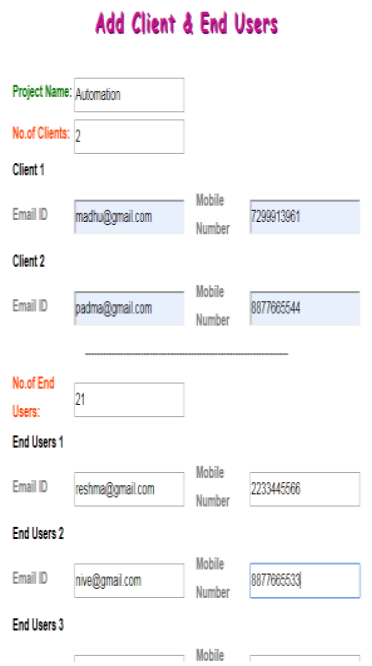

Figure 9 - Stakeholder specification page 
Along with the AHP sheet, guidance to fill the cell will also be there. To encourage the responders to fill the data in the sheet, credits will be provided. Those credits will be later on used to reward the responders. This is to induce the participation of stakeholders. After receiving the responses, the admin will decide the completion of this process by clicking entry completed. After this process, no response from the user will be accepted.

Calculations will be performed by the tool and then the users will be selected for the modules. After this phase, the requirements of the modules will be send to the respective group of users. Again, after receiving the response from the end users, the requirements will be prioritized and the list will be generated.

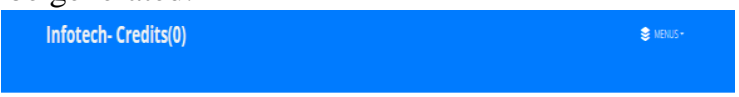

AHP Sheet

\begin{tabular}{|c|c|c|}
\hline Scale & Row Wise Important & Column Virse Inpotant \\
\hline Equally Used & 1 & 1 \\
\hline Moderatly Frequent & 3 & 0.33 \\
\hline Strongly Frequent & 5 & 0.2 \\
\hline Very Strongly Frequent & 7 & 0.14 \\
\hline Extremely Frequent & 9 & 0.11 \\
\hline
\end{tabular}

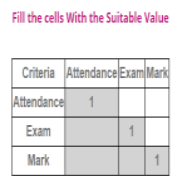

Figure 10 - AHP sheet to stakeholders

Till the list is generated, the status of the project will be 'in-progress'. Once the list is generated, the status will be 'completed'. The admin can view the priority list and select the requirements for the development. Those selected requirements will be removed from the list.

The 'add' option in the 'action' is used to add new requirements in the module of the project. Automatically, that requirement will be send to the respective group of users. Again, the process continues till the updated version of the priority list is generated.

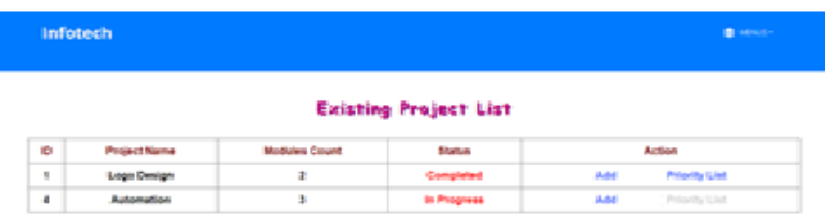

Figure 11 - Status Page

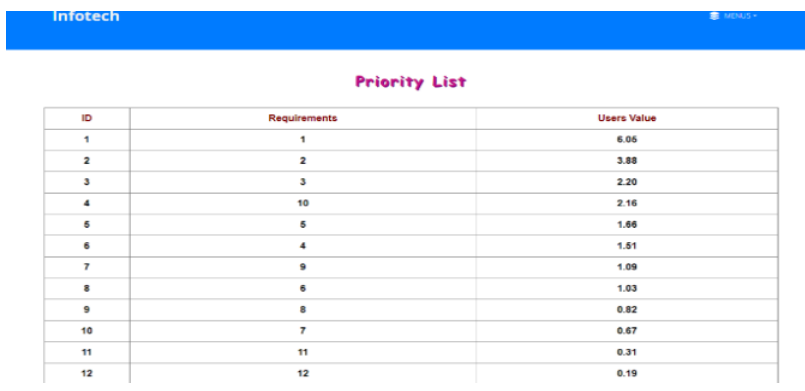

Figure 12 - Priority list

\section{Result of the Experiment}

The result obtained through framework(Excel sheet is used) and the tool is compared.

\begin{tabular}{|r|r|}
\hline \multicolumn{1}{|c|}{ S.No. } & $\begin{array}{r}\text { Requirement } \\
\text { ID }\end{array}$ \\
\hline 1 & $\mathrm{R} 1$ \\
\hline 2 & $\mathrm{R} 2$ \\
\hline 3 & $\mathrm{R} 3$ \\
\hline 4 & $\mathrm{R} 10$ \\
\hline 5 & $\mathrm{R} 5$ \\
\hline 6 & $\mathrm{R} 4$ \\
\hline 7 & $\mathrm{R} 9$ \\
\hline 8 & $\mathrm{R} 6$ \\
\hline 9 & $\mathrm{R} 8$ \\
\hline 10 & $\mathrm{R} 7$ \\
\hline 11 & $\mathrm{R} 11$ \\
\hline 12 & $\mathrm{R} 12$ \\
\hline
\end{tabular}

Figure 3 Through framework -Excel

The result obtained by using Excel sheet is in Fig 13 and the result obtained from the tool is given in fig 12 .

Comparison of results obtained (by proposed framework) using Excel sheet and the tool

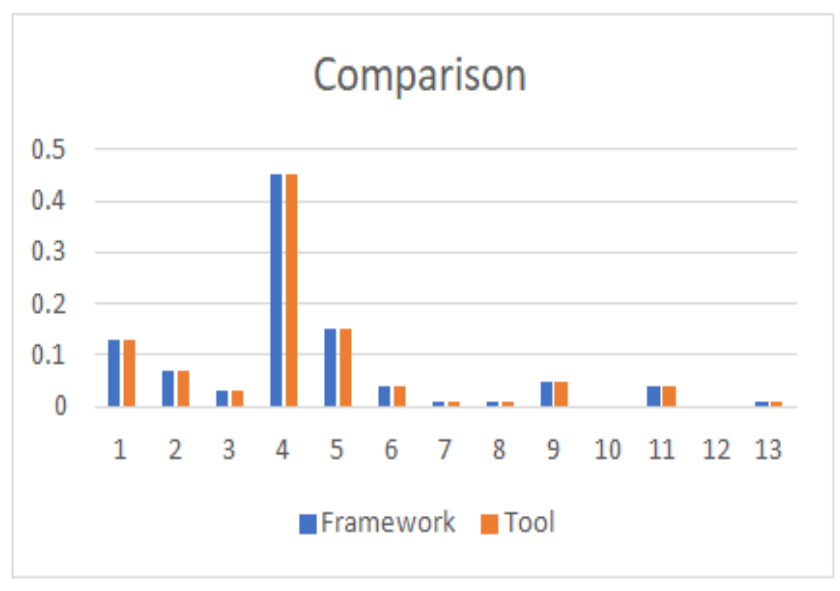

Figure 13 - Comparison of framework(Excel) and tool

Framework in Fig 14 refers using Excel and the tool refers the result obtained by the tool developed

\section{Comparison of AHP and the Tool}

Through the experiment, AHP and the tool was compared considering the following criteria. The experience and the result received is considered to compare them both (Table 4) 


\begin{tabular}{|l|l|l|}
\hline \multicolumn{1}{|c|}{ Criteria } & \multicolumn{1}{|c|}{ AHP } & \multicolumn{1}{|c|}{$\begin{array}{c}\text { Tool developed } \\
\text { forthe proposed } \\
\text { framework }\end{array}$} \\
\hline $\begin{array}{l}\text { Number of stakeholders that } \\
\text { can be handled }\end{array}$ & Small & Large \\
\hline $\begin{array}{l}\text { Number of requirements that } \\
\text { can be handled }\end{array}$ & Small & Large \\
\hline $\begin{array}{l}\text { Possibility of communication } \\
\text { with stakeholders }\end{array}$ & Low & High \\
\hline Adding new requirements & Difficult & $\begin{array}{l}\text { Can } \\
\text { effortlessly }\end{array}$ \\
\hline $\begin{array}{l}\text { Automation of the calculation } \\
\text { process }\end{array}$ & $\begin{array}{l}\text { Partly (If Excel is } \\
\text { used) }\end{array}$ & Optimum \\
\hline $\begin{array}{l}\text { Increasing the Interest among } \\
\text { stakeholders to involve them } \\
\text { in prioritizing the requirement }\end{array}$ & No & High \\
\hline $\begin{array}{l}\text { Flexibility of the method in } \\
\text { case of } \\
\text { stakeholders }\end{array}$ & Low & High \\
\hline \begin{tabular}{l} 
Result \\
\hline
\end{tabular} & $\begin{array}{l}\text { 86\% Similarity in the result obtained } \\
\text { through AHP and the tool }\end{array}$ \\
\hline
\end{tabular}

Table 4 - Comparison of AHP and Tool

\section{CONCLUSION}

This study was based on the existing model from the reviewed literature. Beside the model, the proposed framework is suitable to prepare the priority list of the requirements for large scale projects. Hence the framework results in the compact number of comparison of requirements, compact number of user involvement, which is suitable for large scale software development.

Further, technical team can also be added in prioritization process. They can prioritize based on cohesion in the modules and coupling among the modules. The framework can be enhanced with the technical team.

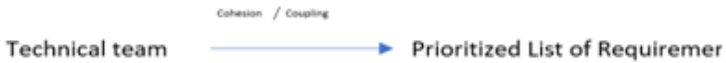

\section{Figure 14 - Inclusion of Technical Team}

First, the modules can be given to the team to find the degree of coupling among them. The result will be the matrix through which the priority among the modules in case of coupling can be assessed. Then the requirements of the modules can be given to the team members to calculate the cohesion level for each requirement. $T$

\section{FUTURE WORK}

The future work of the research is focused on enhancing the tool for the proposed frameworkin the form of mobile app. Some more improvement has to be done to get 100 percent equivalent result with AHP sheet. To find the way to reduce the number of users to rate the requirements based on importance/urgency. Human inducement is required to fill the data. Points can be handled to encourage every responderconsidering the time taken for the response.

\section{REFERENCES}

1. Tschangho John Kim, Modified analytic hierarchy process for project Proposal evaluation: An alternative method for Practica implementation, Reg Sci Policy Pract. 2018; 10:25-35. Wileyonlinelibrary. com/journal/rsp3.

2. IrojuOlaronke, Rhoda Ikono, IshayaGamboo, "An appraisal of software requirement prioritization technique, https://www.researchgate.net/publication/324602923, April 2018

3. SüleymanKıvanç Ekici1, Ahmet Oturgan1, Deniz Kılınç2, Ceyhun Araz3, "Software Requirements Prioritization: A CaseStudy", https://www.researchgate.net/ publication/313879770, 22 February 2017.

4. Aneesa Rida Asghar, Atika Tabassum, Dr. Shahid Nazir Bhatti, Dr. S Asim Ali Shah, The Impact of Analytical Assessment of Requirements Prioritization Models: An Empirical Study, International Journal of Advanced Computer Science and Applications · February 2017 DOI: 10.14569/IJACSA.2017.080240.

5. Philip Achimugu, Ali Selamat, Roliana Ibrahim, MohdNaz'riMahrin, "A systematic literature review of software requirements prioritization research", Information and Software Technology 56 (2014) 568585,09 50-5849, Elsiever

6. Anna Perini a,*, Filippo Ricca b, Angelo Susi , “Tool-supported requirements prioritization: Comparing the AHP and CBRank methods", Information and Software Technology 51 (2009) 10211032 ,

7. An Appraisal Of Software Requirement Prioritization Techniques Iroju Olaronke1, Ikono Rhoda2 And Gambo Ishaya2, 1 Department Of Computer Science, Adeyemi College Of Education, Ondo, Nigeria. 2 Department Of Computer Science And Engineering, Obafemi Awolowo University, Ile-Ife, Nigeria,Vl - 1,Do 10.9734/Ajrcos/2018/40763

8. K Glory Vijayaselvi ,ThirumalaiSelvi R. (2015)," An inclusion of human inducement in engineering the system efficaciously", International Conference "Human Computer Interaction Redefining Corporate Paradigms" on 16th of February 2015, Women's Christian College.

\section{AUTHOR'S PROFILE}

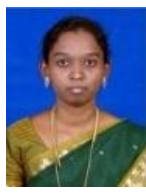

Ms. K Glory Vijayaselvi, is currently pursuing Ph.D. in Bharathiar University, Coimbatore, India and currently working as Assistant Professor in Department of Computer Science (Shift II), Women's Christian College, Chennai, India. Her area of specialization is Software Engineering

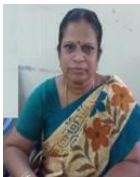

Dr. R. Thirumalaiselvi, is currently working as Assistant Professor in Government Arts College (Men), Autonomous, Department Of Computer Science, Nadanam, Chennai, India. Her areas of specialization are Web Engineering and Web Mining (Data Mining) 